Ambiente \& Água - An Interdisciplinary Journal of Applied Science
ISSN 1980-993X - doi:10.4136/1980-993X
www.ambi-agua.net
E-mail: ambi.agua@gmail.com

\title{
Metals uptake by live yeast and heat-modified yeast residue
}

\author{
doi: 10.4136/ambi-agua.1577
}

Received: 09 Dec. 2014; Accepted: 16 Apr. 2015

\author{
Geórgia Labuto $^{1 *}$; Bianca Trama ${ }^{1}$; Geison Castro da Silveira Gueller ${ }^{2}$; Bruna de Souza \\ Guarnieri $^{3}$; Fernando Vitorino da Silva ${ }^{1}$; Roberta Collazo ${ }^{1}$ \\ ${ }^{1}$ Universidade Federal de São Paulo (Unifesp), Diadema, SP, Brasil \\ Instituto de Ciências Ambientais Químicas e Farmacêuticas \\ ${ }^{2}$ Universidade de São Paulo (USP), São Paulo, SP, Brasil \\ Instituto de Biociências \\ ${ }^{3}$ Universidade de São Paulo (USP), São Paulo, SP, Brasil \\ Escola de Artes, Ciências e Humanidades \\ "Corresponding author: e-mail: geolabuto@gmail.com, \\ btrama@gmail.com,g3ison@gmail.com, brunasguarnieri@gmail.com, \\ fernando_vitorino@terra.com.br, roberta_collazo@yahoo.com.br
}

\begin{abstract}
This study evaluated the biosorption of $\mathrm{Cd}^{2+}, \mathrm{Cr}^{3+}, \mathrm{Pb}^{2+}$ and $\mathrm{Cu}^{2+}$ at $\mathrm{pHs} 3,4,5$ and 6 for Saccharomyces cerevisiae both alive and biologically inactivated by different heating procedures (oven, autoclave or spray dry technique originated from alcohol industry). The material inactivated by autoclave (IA, at $120^{\circ} \mathrm{C}, 30 \mathrm{~min}$ ) had the best performance for metals uptake: $1.88 \pm 0.07\left(\mathrm{Cu}^{2+}\right), 2.22 \pm 0.02\left(\mathrm{Cr}^{3+}\right)$ and $1.57 \pm 0.08 \mathrm{~g} \mathrm{~kg}^{-1}\left(\mathrm{~Pb}^{2+}\right)$. For $\mathrm{Cd}^{2+}$; while the material inactivated by spray dry (RY) presented the higher sorption capacity, $2.30 \pm 0.08 \mathrm{~g} \mathrm{~kg}^{-1}$. The sorption studies showed that the biosorbent materials presented different sorption capacities and an ideal sorption $\mathrm{pH}$. The sorption sites were investigated by potentiometric titration and FT-IR and showed that different heating processes used to inactivate biological samples produce materials with different characteristics and with a diverse sorption capacity due to modification of the available sorption sites. This suggests that inactivation by heating can be an alternative to improve the performance of biosorbents. The main sorption sites for each material were phenolic for live yeast (LY) and carboxylic for yeast inactivated by heating in an autoclave (IA).
\end{abstract}

Keywords: biosorption, metals sorption, modification of the biosorbent, sorption sites.

\section{Sorção de metais por levedura viva e resíduo de levedura modificado por processos de aquecimento}

\section{RESUMO}

Saccharomyces cerevisiae viva e biologicamente inativada por diferentes processos de aquecimento (forno, autoclave ou spray dry) foram empregadas para biossorção de $\mathrm{Cd}^{2+}, \mathrm{Cr}^{3+}$, $\mathrm{Pb}^{2+}$ e $\mathrm{Cu}^{2+}$ em pHs 3, 4, 5 e 6 . O material inativado por autoclave (IA, a $120^{\circ} \mathrm{C}, 30 \mathrm{~min}$ ) teve o melhor desempenho para a sorção de metais: 1,88 $\pm 0,07\left(\mathrm{Cu}^{2+}\right), 2,22 \pm 0,02\left(\mathrm{Cr}^{3+}\right)$ e 1,57 \pm $0,08 \mathrm{~g} \mathrm{~kg}^{-1}\left(\mathrm{~Pb}^{2+}\right)$. Para $\mathrm{Cd}^{2}+\mathrm{o}$ material inativado por spray dry $(\mathrm{RY})$ apresentou a maior capacidade de sorção, $2,30 \pm 0,08 \mathrm{~g} \mathrm{~kg}^{-1}$. Os estudos de sorção mostraram que os materiais 
biossorvente apresentaram diferentes capacidades de sorção e pH ideal de sorção. Os sítios de sorção foram investigados por titulação potenciométrica e FT-IR e denotam que diferentes processos de aquecimento empregados para inativação biológica produzem materiais com características diversas e com capacidade de sorção distintos devido a modificação dos sítios de sorção disponíveis. Isto sugere que a inativação por aquecimento pode ser uma alternativa para melhorar o comportamento de biossorventes. Os principais sítios de sorção para cada material foram grupos fenólicos para a levedura viva (LY) e grupos carboxílicos para levedura inativada em autoclave (IA).

Palavras-chave: biossorção, modificação do biosorvente, sítios de sorção, sorção de metais.

\section{INTRODUCTION}

Biological materials alive or dead have been used successfully as biosorbent for metals or organic compounds since 80's (Madrid and Cámara, 1997). The main disadvantages of using living organisms - which have led to a search for using inactivated organisms - are: a) they are unable to regenerate for reuse; b) the pathogenic feature of the material; c) the need to know and control the best growing conditions in the presence of the analyte; and d) the toxicity of such analytes may affect the biological material leading to the inhibition of its development or even its death, stopping the sorption process (Vegliò and Beolchini, 1997). On the other hand, the mechanisms not dependent on metabolism are faster, without major influences of temperature in the range of 30 to $40^{\circ} \mathrm{C}$, and are directly related to the $\mathrm{pH}$ of the medium (Vegliò and Beolchini, 1997). The $\mathrm{pH}$ dependence favors the use of inactivated biological materials. Thermal inactivation is frequently mentioned as a way to interrupt the metabolism of biological materials employed in studies of biosorption (Arica et al., 2003; Bayramoğlu and Arica, 2008).

While the mechanisms of change related to macromolecular cell death during heat treatment are not fully known, we know that thermal inactivation creates a new material, once it has caused the irreversible denaturation of the cell wall (which is composed of lipids, phospholipids, polysaccharides and proteins), membranes, ribosomes, and nucleic acids (Lee and Kaletunç, 2002). Thermal inactivation is employed to interrupt the metabolism for biosorption and also has been used to improve their sorption capacity (Arica et al., 2005; Gürişik et al., 2004; Bayramoğlu and Arica, 2008). However, such items do not discuss how biological inactivation by heating processes affects the sorption sites of biosorbents, contributing to the improvement of sorption capacity.

This work reports the influence of heating inactivation (HI) of Saccharomyces cerevisiae from the alcohol industry on metals uptake and available sorption sites. S. cerevisiae is a costeffective biosorbent because it is largely obtainable as a residue from the ethanol industry (c.a. 420,000 tons/year only in Brazil) and is nonpathogenic. The cell wall is composed of glucans, mannans, chitin, protein and lipid, all rich in organic functional groups with high potential for metals uptake (Volesky, 2004).

\section{MATERIALS AND METHODS}

\subsection{Yeast origin and heating inactivation procedures}

All experiments were conducted with the same initial biomasses that originated from the first ethanol fermentation which was stored frozen until ready for use (except for the biomass inactivated by spray dry). After thawing, the biomass was filtered with Filter Pro $0.45 \mu \mathrm{m}$, $33 \mathrm{DM}$ (Aprolab, Brasil) then washed with distilled deionized water. The laboratory inactivation of yeast was conducted immediately after filtering. 
Saccharomyces cerevisiae provided from ethanol industry was employed in four forms: i) live yeast (LY); ii) inactivated by heating in an oven (IO): $120^{\circ} \mathrm{C}, 2 \mathrm{~h}$; iii) inactivated by heating in an autoclave (IA): $30 \mathrm{~min}, 120^{\circ} \mathrm{C}$, afterward dried in oven at $60^{\circ} \mathrm{C}$ until constant weight; and iv) inactivated by the spray dry technique (RY) by the ethanol industry.

To verify that the material had been inactivated, the inoculations of living matter and materials were submitted to the inactivation procedures in Petri dishes containing culture medium for yeast $\left(20 \mathrm{~g} \mathrm{~L}^{-1}\right)$ YPD agar (Sigma-Aldrich). The inocula were incubated in a microbiological chamber at $30^{\circ} \mathrm{C}$ for 24 hours. After that, the absence of growth in the plates containing yeast submitted to the inactivation procedures was confirmed by comparison with the inocula of live yeast obtained from the alcohol industry. The whole procedure of preparation of the suspension and inoculation was performed under sterile conditions within a laminar flow hood, and disinfected with $70 \%$ alcohol and submission to UV radiation for five minutes. All solutions and materials used to prepare the suspension for the inoculation and were autoclaved for 30 minutes at $120^{\circ} \mathrm{C}$.

\subsection{Characterization of biosorbent materials}

Potentiometric titration of sorption sites: Three aliquots of $50 \mathrm{mg}$ of each type of biosorbent were suspended in $50 \mathrm{~mL}$ of $0.1 \mathrm{~mol} \mathrm{~L}^{-1} \mathrm{KNO}_{3}$ and the initial $\mathrm{pH}$ was determined. The sorption sites were potentiometrically titrated up to $\mathrm{pH} 2.0$ with standardized $\mathrm{HNO}_{3}$ solutions, according to (Araújo et al., 2007). Other 3 aliquots were titrated until pH 12.0 with standardized $\mathrm{KOH}$ solutions.

The mathematic model assumes that the material contains $n$ binding sites of the main metal ions, and treats these sites as discrete monoprotic weak acids, $\mathrm{HL}_{\mathrm{n}}$, the consumption of $\mathrm{H}^{+}$by these sites can be expressed by the following Equação 1 (Wang et al., 1998):

$$
\Delta V=\frac{V_{0}}{C}\left[\begin{array}{l}
\sum_{n=1}^{n}\left[C_{n}\left(\frac{K_{a n}}{\left[H^{+}\right]+K_{a n}}-\frac{K_{a n}}{\left[H^{+}\right]_{0}+K_{a n}}\right)\right]+\left[\mathrm{OH}^{-}\right]-\left[\mathrm{H}^{+}\right]-\left[\mathrm{OH}^{-}\right]_{0}+\left[\mathrm{H}^{+}\right]_{0} \\
\left.+\mathrm{C}_{\mathrm{C}}\left(\frac{10^{-16.6}-\left[\mathrm{H}^{+}\right]^{2}}{\left[\mathrm{H}^{+}\right]^{2}+10^{-6.3}\left[\mathrm{H}^{+}\right]+10^{-16.6}}-\frac{10^{-16.6}-\left[\mathrm{H}^{+}\right]_{0}^{2}}{\left[\mathrm{H}^{+}\right]_{0}^{2}+10^{-6.3}\left[\mathrm{H}^{+}\right]_{0}+10^{-16.6}}\right)\right]
\end{array}\right]
$$

where:

$\Delta \mathrm{V}=$ cumulative volume of acid/base added $(\mathrm{mL}) ;$

$\mathrm{V}_{0}=$ initial volume of suspension solution $(\mathrm{mL})$;

$\mathrm{C}=$ concentration of acid/base added $\left(\mathrm{mol} \mathrm{L}^{-1}\right)$;

$\mathrm{C}_{\mathrm{n}}=$ concentration of the acid site, $\mathrm{C}_{\mathrm{n}}=\left[\mathrm{HL}_{\mathrm{n}}\right]+\left[\mathrm{L}_{\mathrm{n}}^{-}\right]\left(\mathrm{mol} \mathrm{L}^{-1}\right)$;

$\mathrm{C}_{\mathrm{c}}=$ total carbonate concentration $\left(\mathrm{mol} \mathrm{L}^{-1}\right)$;

$\mathrm{K}_{\mathrm{an}}=$ acidity constant of $\mathrm{HL}_{\mathrm{n}}\left(\mathrm{mol} \mathrm{L}^{-1}\right)$;

$\left[\mathrm{OH}^{-}\right]_{0},\left[\mathrm{H}^{+}\right]_{0}=$ initial concentration of hydroxyl and ions $\mathrm{H}^{+}\left(\mathrm{mol} \mathrm{L}{ }^{-1}\right)$, respectively;

$10^{-6,3}=$ first acidity constant $\left(\mathrm{K}_{\mathrm{a} 1}\right)$ of $\mathrm{H}_{2} \mathrm{CO}_{3}$;

$10^{-16,6}=$ overall acidity constant $\left(\mathrm{K}_{\mathrm{a} 1} \times \mathrm{K}_{\mathrm{a} 2}\right)$ of $\mathrm{H}_{2} \mathrm{CO}_{3}$.

The first factor inside the parenthesis of equation 1 represents the consumption of hydrogen ions by the material, taking into account $\mathrm{n}$ complexation sites; the second factor represents the consumption by water; and the third factor represents the consumption by carbonate species. Thus, if $\mathrm{pH}$ is the unique dependent variable of the equation, a non-linear 
regression of the obtained data is run until fitting them to the equation will yield the constant values of acidity and the concentration of ligant sites as results (Lemos and Takiyama, 1999). The acid-base titration curves were used to estimate the constants of acidity and the concentrations of the acidic sites of the biosorbent material through the non-linear regression using the equation 1 . The non-linear regression of the titration curves, performed with Sigma Plot 8.0 software (Statistical Solutions, USA), was used to infer the acid-base sorption site characteristics.

Changes in the main functional groups present in LY, IA, IO and RY biosorbent materials were investigated by use of a Fourier transform infrared spectrometer (Bomem MB 102, Austria). Portions of each material was added to $\mathrm{KBr}$ previously dried in an oven and pressed to produce tablets that had been analyzed to obtain infrared spectra.

\subsection{Metals uptake by the yeast biosorbent materials}

A quantity of $100.00 \mathrm{mg}$ of LY, IA, IO and RY were conditioned in $15 \mathrm{~mL}$ of $\mathrm{KNO}_{3} 0.5 \mathrm{~mol} \mathrm{~L}^{-1}$ and the $\mathrm{pH}$ was set to $3,4,5$ or 6 . The conditioned materials were centrifuged and re-suspended in $5 \mathrm{~mL}$ of individual metals solutions containing $50 \mathrm{mg} \mathrm{L}^{-1}$ of each metal $\mathrm{Cd}^{2+}, \mathrm{Cr}^{3+}, \mathrm{Pb}^{2+}$ or $\mathrm{Cu}^{2+}$ in $\mathrm{KNO}_{3} 0.5 \mathrm{~mol} \mathrm{~L}^{-1}$ and pHs previously set to $3,4,5$ or 6.

The suspensions were shacked $\left(250 \mathrm{rpm}, 10 \mathrm{~min}, 25^{\circ} \mathrm{C}\right)$, centrifuged $(2 \mathrm{~min}, 3400 \mathrm{rpm})$ and the supernatants were transferred to different flasks to stop the contact with the metal solutions. The work solutions and supernatants of biosorption were analyzed using an ICP OES (Varian RD, USA) - spectral lines $226.502 \mathrm{~nm} \mathrm{Cd(II),} 205.560 \mathrm{~nm} \mathrm{Cr}(\mathrm{III})$, $213.598 \mathrm{~nm} \mathrm{Cu}$ (II) and $182.143 \mathrm{~nm} \mathrm{~Pb}(\mathrm{II}), 1.20 \mathrm{~kW}$ power, plasma flow $15 \mathrm{~L} \mathrm{~min}^{-1}$, auxiliary gas $1.50 \mathrm{~L} \mathrm{~min}^{-1}$, nebulizer flow $0.9 \mathrm{~L} \mathrm{~min}^{-1}$ and the quantification limits (LOQ) were $0.25 ; 0.5,1.0$ e $1.0 \mathrm{mg} \mathrm{L}^{-1}$, respectively.

The metals uptakes were determined by the difference between the metals concentration of individual solutions prepared in $\mathrm{KNO}_{3} 0.5 \mathrm{~mol} \mathrm{~L}^{-1}$ in the four working $\mathrm{pHs}$ and the supernatants obtained after contact with these biosorbent solutions and these differences were used to calculate the mass of each metal biosorbed by the respective biomasses (LY, IA, IO and RY).

\section{RESULTS AND DISCUSSION}

\subsection{Metals uptake by the yeast biosorbent materials}

Changes in metals uptake are expected considering that the characterization of biosorbent materials denotes that $\mathrm{HI}$ results in different materials, with a diverse sorption sites distribution. Overall, all heating processes improved biosorbent capacity (Figure 1 and Table 1). This behavior is related in literature by different materials (Arica et al., 2005; Bayramoğlu and Arica, 2008).

The evaluation of the effectiveness of the inactivation methods employed was checked by the inoculation of all materials on YPD. The materials submitted to the inactivation processes were checked to ensure that they did not present metabolic action on observed sorption phenomena, depending only on the interaction of metals and sorption sites available on the surfaces of the modified materials.

In general, IA was the best biosorbent for all analytes in all $\mathrm{pHs}$, with the exception of $\mathrm{Cd}^{2+}$ (Figure 1) for which RY was the best biosorbent. Given that the sorption sites and species of metals in solution are Pearson's acids and bases, it is possible to infer about the probable sorption sites involved in metals uptake. The $\mathrm{Cd}^{2+}$ is the predominant species in all studied pHs (100\%) (Baes and Mesmer, 1976), and this fact may explain the small variation of $\mathrm{Cd}$ uptake for these $\mathrm{pHs}$ independent of the evaluated material. 
Thus, the variation of sorption may be related to three mechanisms: 1) complexation with sorption sites; 2) electrostatic attraction; and 3) metabolism dependence, which can be discarded since $\mathrm{Cd}^{2+}$ is very toxic to cells and promotes apoptosis (Gadarin et al., 2010). The order of $\mathrm{Cd}^{2+}$ uptake is $\mathrm{RY}>\mathrm{IA}>\mathrm{IO}>\mathrm{LY}$, where IA uptake is around 2.5 times that removed by IO (Table 1). Since RY has the higher possibilities of soft bases to complex $\mathrm{Cd}^{2+}$ (Pearson's soft acid) the superior analyte uptakes by RY could be related to the sorption sites hydroxyl which accounts for about $93.1 \%$ of the sites available for this material.
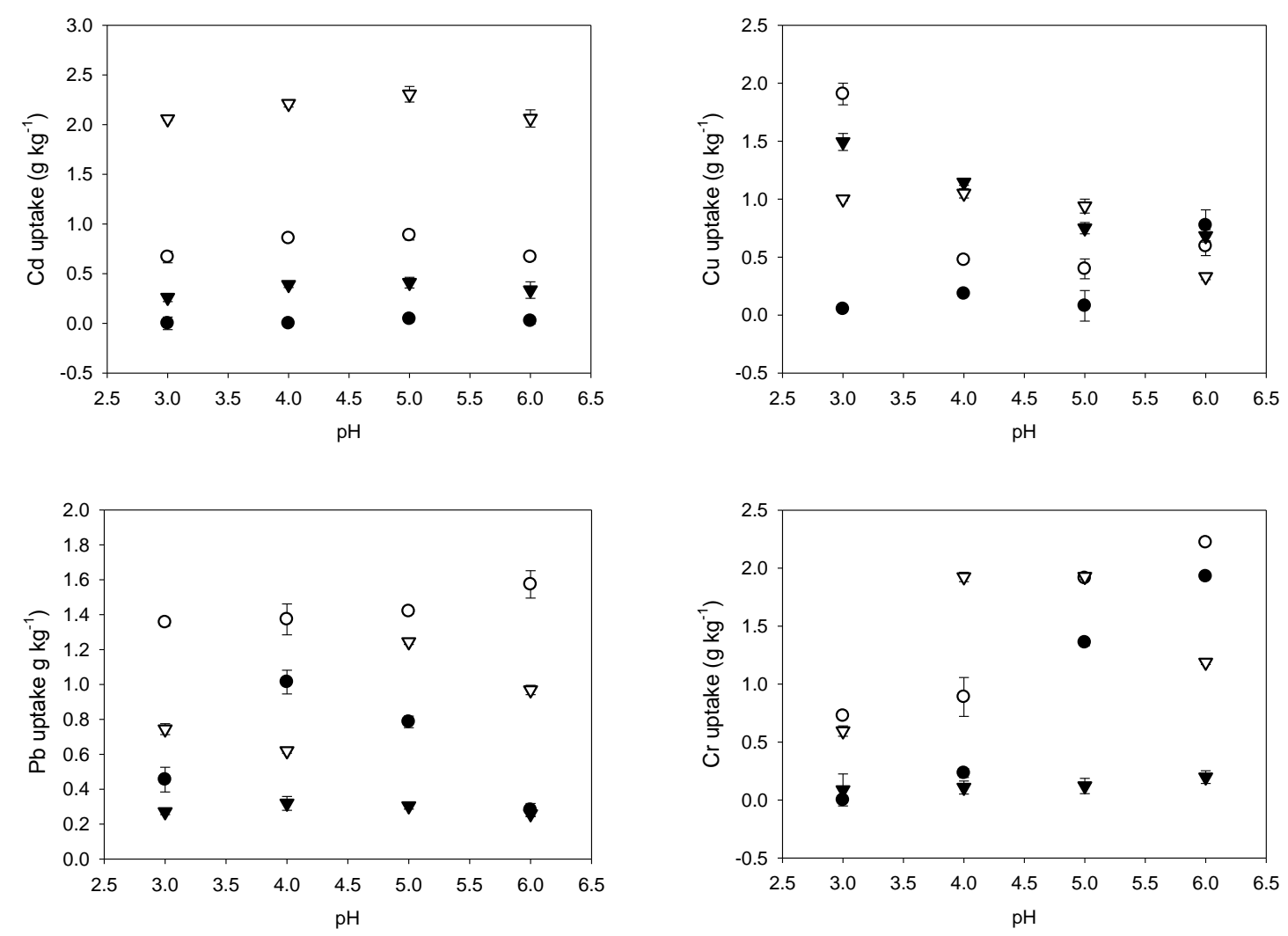

Figure 1. Metals removed at different $\mathrm{pHs}(\mathrm{n}=3)$.

Note: $\mathbf{o}=$ IA (Inactivated by Autoclave), $\boldsymbol{\nabla}=$ IO (Inactivated by Oven), $\nabla=$ RY (Residue of Yeast from ethanol industry) and $\bullet=\mathrm{LY}$ (Live Yeast alive).

The $\mathrm{Cu}^{2+}$ is a free cation in $\mathrm{pHs}$ from 3 to 5 . At $\mathrm{pH} 6, \mathrm{CuOH}^{+}$and $\mathrm{Cu}_{2}(\mathrm{OH})_{2}{ }^{2+}$ manifest (Baes and Mesmer, 1976), which could explain the decreased uptake of the analyte at this $\mathrm{pH}$ for all inactivated materials, since the probable interaction between them and this analyte is the electrostatic interaction. For all pHs the sorption sites of $\mathrm{RY}$ are protonated, suggesting that the mechanism is related to covalent bonds and not to an electrostatic attraction. Considering that $\mathrm{Cu}^{2+}$ is a Pearson's borderline acid, all sorption sites are able to complex with the analyte. While $\mathrm{Cu}^{2+}$ sorption increased at $\mathrm{pH} 6$ for $\mathrm{LY}$, the opposite behavior was observed for the inactivated materials. This behavior can be related to the fact that copper is an essential element for mitochondrial respiration, for carbon and nitrogen metabolism, for oxidative stress protection, besides being important for cell wall synthesis (Hänsch and Mendel, 2009). Furthermore, the best conditions for yeast development are between $\mathrm{pH} 5-6$, which might have contributed to the higher sorption capacity presented by LY at this $\mathrm{pH}$.

The $\mathrm{Pb}^{2+}$ is present as a free cation in solution for all $\mathrm{pHs}$ studied. Thus, the changes of sorption are related to the influence of $\mathrm{pH}$ on the available sorption sites. For $\mathrm{Pb}^{2+}$, the retention rate obtained for LY was $48.34 \%$ of available metal in work solutions at $\mathrm{pH} 4$. For $\mathrm{RY}$, the 
retention was around $55.74 \%$ at $\mathrm{pH} 5.0$ and $59 \%$ for IO for all $\mathrm{pHs}$ from the initial available metals in solution, with the highest retention percentage for $\mathrm{pH} 6.0$, on the order of $65.26 \%$. For this metal RY, IA and LY presented similar sorption capacities (Table 1), which suggests that the uptake for this analyte is not metabolism-dependent even for the LY. In addition, the slight increasing of sorption observed for IO at $\mathrm{pH} 4$ could be related to the deprotonation of carboxylic sites at this $\mathrm{pH}$. This corroborates the hypothesis that these sorption sites are responsible for the retention of the analyte.

$\mathrm{The} \mathrm{Cr}^{3+}$ is a Pearson's hard acid and produces six species in solutions with equilibrium varying with $\mathrm{pH}$. The distribution of the $\mathrm{Cr}^{3+}$ species in diluted solution according to $\mathrm{pH}$ is: $\mathrm{pH}<3=100 \% \mathrm{Cr}^{3+} ; \mathrm{pH} 4=\mathrm{Cr}^{3+}(72 \%)$ and $\mathrm{Cr}_{2}(\mathrm{OH})_{2}{ }^{4+}(28 \%) ; \mathrm{pH} 5=\mathrm{Cr}^{3+}$ (14\%), $\mathrm{CrOH}_{2}{ }^{+}(30 \%), \mathrm{Cr}_{3}(\mathrm{OH})_{4}{ }^{5+}(50 \%), \mathrm{Cr}_{2}(\mathrm{OH})_{2}{ }^{4+}(4 \%)$ and $\mathrm{Cr}(\mathrm{OH})_{4}{ }^{-}(2 \%) \mathrm{Cr} ; \mathrm{pH} 6=\mathrm{CrOH}_{2}{ }^{+}$ (15\%), $\mathrm{Cr}(\mathrm{OH})_{2}{ }^{+}(10 \%)$ and $\mathrm{Cr}_{3}(\mathrm{OH})_{4}{ }^{+5}(75 \%)$ (Baes and Mesmer, 1976). The $\mathrm{Cr}^{3+}$ uptake was affected by $\mathrm{pH}$ increment for all materials, suggesting that the variation of chemical species can be affected by this parameter. Probably, the chromium species present in solution, which changes with $\mathrm{pH}$, and their interactions with the available sorption sites are responsible for the sorption increasing with $\mathrm{pH}$.

Inactivation provides a better performance of biosorbent due to the changes promoted by the different heating processes on available sorption sites. In general, the material inactivated by autoclave (IA) presented the best performance for metals uptakes. The yeast residue (RY) only presented a higher sorption for $\mathrm{Cd}$. The solution of inactive materials has advantages, such as the need to control the conditions of microorganism growth which involves completely knowing its metabolism and life cycle, no danger of the toxicity of the analytes impeding biosorbent development, and the simplicity of storage and transportation of the biosorbent in the case of commercial uses.

Sorption site availability depends on other factors, such as the chemical function and quantity of sorption sites, accessibility, chemical state and affinity of the analyte (Hänsch and Mendel, 2009). In addition, the chemical neighborhood can differentiate the sites of the same chemical function, through withdrawing or donating groups that affect the electronic density of the sorption sites with the same theoretical uptakes capacity, making them more positive or negative (March, 1992).

Table 1. General data of metals uptake by different biological materials (100.00 $\mathrm{mg}$ of biological material, $50 \mathrm{mg} \mathrm{L}^{-1}$ of different metals in $\mathrm{KNO}_{3} 0.5 \mathrm{~mol} \mathrm{~L}^{-1}, \mathrm{n}=3$ ).

\begin{tabular}{ccccccccc}
\hline \multicolumn{7}{c}{ Metal uptakes $\left(\mathrm{g} \mathrm{kg}^{-1}\right)$} \\
$\begin{array}{c}\text { Biosorbent } \\
\text { Material }\end{array}$ & $\mathrm{Cd}$ & $\mathrm{pH}$ & $\mathrm{Cu}$ & $\mathrm{pH}$ & $\mathrm{Pb}$ & $\mathrm{pH}$ & $\mathrm{Cr}$ & $\mathrm{pH}$ \\
\hline $\mathrm{IA}$ & $0.87 \pm 0.05$ & 5 & $1.90 \pm 0.09$ & 3 & $1.57 \pm 0.08$ & 6 & $2.22 \pm 0.02$ & 6 \\
$\mathrm{IO}$ & $0.41 \pm 0.05$ & 5 & $1.49 \pm 0.07$ & 3 & $0.32 \pm 0.04$ & 4 & $1.22 \pm 0.06$ & 5 \\
$\mathrm{RY}$ & $2.30 \pm 0.08$ & 5 & $1.05 \pm 0.04$ & 4 & $1.2 \pm 0.1$ & 5 & $0.54 \pm 0.01$ & 5 \\
$\mathrm{LY}$ & $0.04 \pm 0.03$ & 6 & $0.77 \pm 0.03$ & 6 & $1.01 \pm 0.07$ & 4 & $1.93 \pm 0.01$ & 6 \\
\hline
\end{tabular}

$\mathrm{LY}=$ live yeast; $\mathrm{IO}=$ inactivated by heating in an oven, $120^{\circ} \mathrm{C}, 2 \mathrm{~h} ; \mathrm{IA}=$ inactivated by heating in an autoclave, $30 \mathrm{~min}, 120^{\circ} \mathrm{C}$, afterward dried in oven at $60^{\circ} \mathrm{C}$ until constant weight, and $\mathrm{RY}=$ inactivated by spray dry technique (RY).

\subsection{Characterization of biosorbent materials}

Potentiometric titration of acid sites: The cell wall of $S$. cerevisiae is composed by mannoproteins (30-50\%), 1,6- $\beta$-Glucan (5-10\%), 1,3- $\beta$-Glucan (30-45\%) and chitin (1,5-6\%) 
(Klis, 1994). According to other authors, the cell wall is also composed of c.a. $6 \%$ of lipids, $9 \%$ of glycoprotein, $25 \%$ of mannane and $43 \%$ of glycans (Avery and Tobin, 1993; Chaud and Sgarbieri, 2006).

These components present functional groups such as amine, amide, imidazol, thioethers, phosphate, carboxylic, thiol, phenolic and hydroxyl which present different affinities by metallic species (Shiewer and Volesky, 2000), pKa and acid-base classification according to Pearson theory (Pearson, 1968). Heating can cause loss of secondary or tertiary structure of cell wall proteins, which affects the sorption capacity of a biosorbent and its behavior by changes in functional groups' availability and exposure. Table 2 shows the differences found between $S$. cerevisiae inactivated by heat applied by different inactivation methods. According to the titration approach, the materials are chemically different and have not just different sorption sites but also presented a diverse percentual distribution when sorption sites of a same chemical function were present. Figure 2 presents the titration curves of sorption sites for the different materials and the best-fitting curve to predict the sorption sites.

The FT-IR spectra (Figure 3) of IA, IO, RY and LY present functional groups in the region between $3000-3750 \mathrm{~cm}^{-1}$ and $2940-2820 \mathrm{~cm}^{-1}$, which were attributed to $\mathrm{OH}$. The peaks at 1730 $1640 \mathrm{~cm}^{-1}$ can be related to carbonyl groups $(\mathrm{C}=\mathrm{O})$ or aromatic C-C. The peaks at 1499 and1595 can be attributed to axial strain of aromatic $\mathrm{C}=\mathrm{C}$, and are more defined to LY, IA and IO, respectively. The band at 1260 and $1000 \mathrm{~cm}^{-1}$ was related to the axial strain of C-O bound from phenol and $\mathrm{OH}$. It is worthy of mention that there are considerable differences between LY and the other bioabsorbents inactivated by heating, which confirms that the inactivation methods change the available sorption sites.

The diverse characteristics of sorption sites presented by the materials submitted to different biological inactivation processes could be related to the denaturation of protein and carbohydrate chains, disrupting the cell wall, which can expose different sites not previously accessible to the Biosorption (Halasz and Lasztity, 1991).
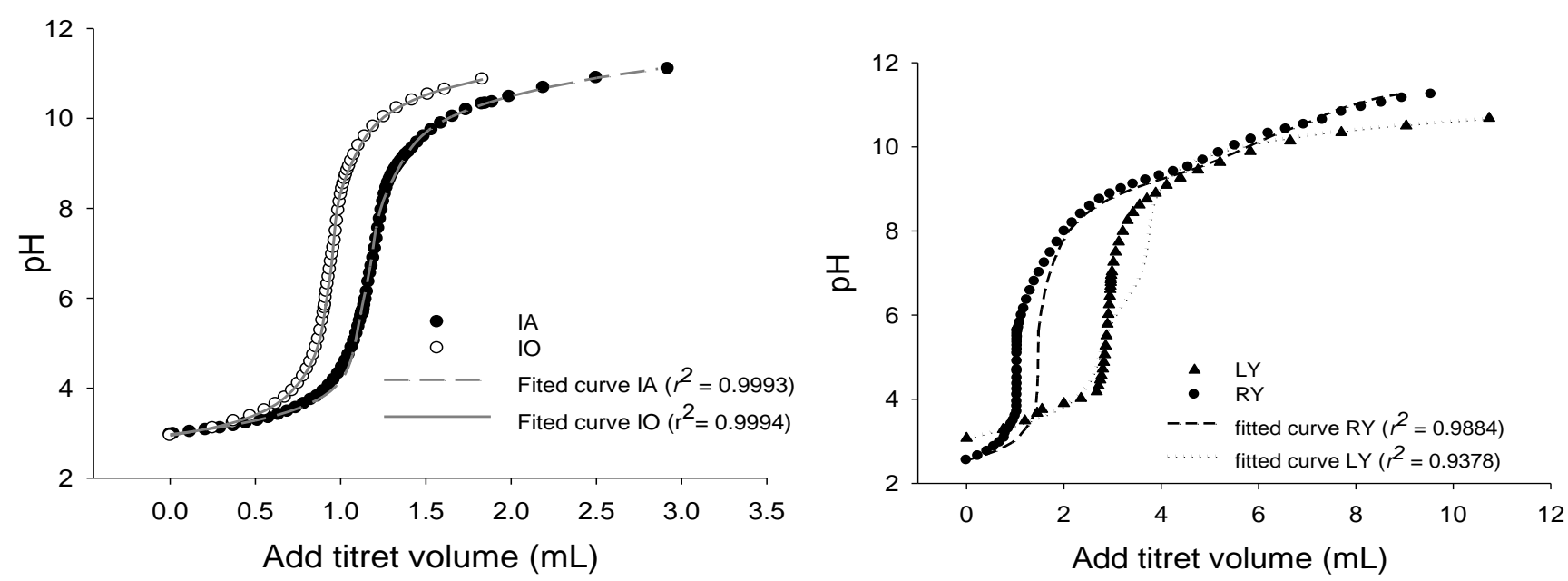

Figure 2. Titration curves of acidic sites for IA = Inactivated by Autoclave, IO = Inactivated by Oven, $\mathrm{RY}=$ Residue of Yeast from ethanol industry and LY $=$ Live Yeast $(n=3)$. 
Table 2. Sorption sites $\left(\mathrm{S}_{\mathrm{n}}\right)$ characterized by potentiometric titration for $S$. cerevisiae alive and inactivated by diverse processes.

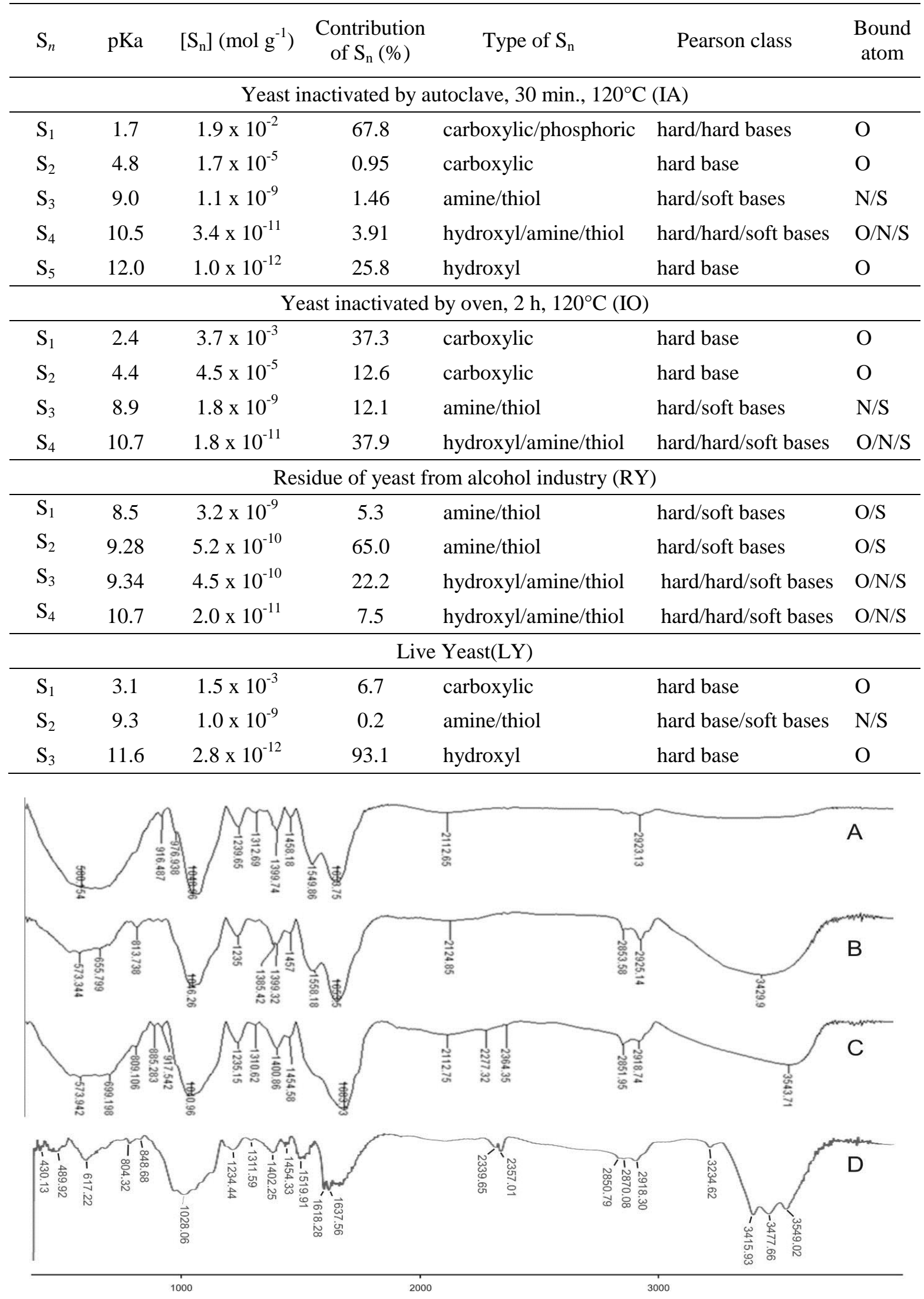

Figure 3. Fourier Infrared spectra presenting the main functional groups for A) LY = Live Yeast, B) IA = Inactivated by Autoclave, C) IO = Inactivates by Oven, D) RY = Residue of Yeast from ethanol industry. Resolution: $4 \mathrm{~cm}^{-1}$ at 20 scans $\mathrm{min}^{-1}$. 


\section{CONCLUSIONS}

Different kinds of heating have been used to inactivate biological material employed as biosorbent. The influence of the different kinds of heating should be monitored because these procedures can affect the sorption sites and their distribution on the biosorbents, modifying sorption capacities and the mathematical models that describe the biosorption phenomena. Overall, inactivation in an autoclave promotes the largest uptake of toxic metals.

\section{ACKNOWLEDGEMENTS}

The authors are gratefully to FAPESP (Proc. 2007/53860-6) and CNPq for students fellowships.

\section{REFERENCES}

ARAÚJO, G. C. L.; LEMOS, S. G.; FERREIRA, A. G.; FREITAS, H.; NOGUEIRA, A. R. A. Effect of pre-treatment and supporting media on $\mathrm{Ni}(\mathrm{II}), \mathrm{Cu}(\mathrm{II}), \mathrm{Al}(\mathrm{III})$ and $\mathrm{Fe}(\mathrm{III})$ sorption by plant root material. Chemosphere, v. 68, p. 537-545, 2007. http://dx.doi.org/10.1016/j.chemosphere.2006.12.054

ARICA, M. Y.; ARPA, C.; KAYA, B. Comparative biosorption of mercuric ions from aquatic systems by immobilized live and heat - inactivated Trametes versicolor and Pleurotus sajur - caju. Bioresource Technology, v. 89, p. 145-154, 2003. http://dx.doi.org/10.1016/S0960-8524(03)00042-7

ARICA, M. Y.; TÜZÜN, İ.; YALÇIN, E.; İNCE, O.; BAYRAMOĞLU, G. Utilisation of native, heat and acid-treated microalgae Chlamydomonas reinhardtii preparations for biosorption of $\mathrm{Cr}(\mathrm{VI})$ ions. Process Biochemistry, v. 40, p. 2351-2358, 2005. http://dx.doi.org/10.1016/j.procbio.2004.09.008

AVERY, S. V.; TOBIN, J. M. Mechanisms of adsorption of hard and soft metal ions to Saccharomyces cerevisiae and influence of hard and soft ions. Apllied and Environmental Microbiology, v. 59, p. 2851-2856, 1993.

BAES, C. F.; MESMER, R. E. The hydrolysis of cations. New York: Wiley-Interscience Publication, 1976.

BAYRAMOĞLU, G.; ARICA, M. Y. Removal of heavy mercury(II), cadmium(II) and zinc(II) metal ions by live and heat inactivated Lentinus edodes pellets. Chemical Engineering Journal, v. 143, p. 133-140, 2008.

http://dx.doi.org/10.1016/j.cej.2008.01.002

CHAUD, S. G.; SGARBIERI, V. C. Fracionamento e caracterização química da parede celular de levedura. Ciência e Tecnologia dos Alimentos, v. 26, p. 369-379, 2006.

GARDARIN, A.; CHÉDIN, S.; LAGNIEL, G.; AUDE, J. C.; GODAT, E.; CATTY, P.; LABARRE, J. Endoplasmic reticulum is a major target of cadmium toxicity in yeast. Molecular Microbiology, v. 76, p. 1034-1048, 2010. http://dx.doi.org/10.1111/j.13652958.2010.07166.x 
GÜRIŞIK, E.; ARICA, M. Y.; BEKTAŞ, S.; GENÇ, Ö. Comparison of the Heavy Metal Biosorption Capacity of Active, Heat-Inactivated and NaOH-Treated Phanerochaete chrysosporium Biosorbents. Engineering in Life Sciences, v. 4, p. 86-89, 2004. http://dx.doi.org/10.1002/elsc.200420011

HALASZ, A.; LASZTITY, R. Use of Yeast Biomass in Food Production. Boca Ratón: CRC Press, 1991. p. 115.

HÄNSCH, R.; MENDEL, R. R. Physiological functions of mineral micronutrients (Cu, Zn, $\mathrm{Mn}, \mathrm{Fe}, \mathrm{Ni}, \mathrm{Mo}, \mathrm{B}, \mathrm{Cl})$. Current Opinion in Plant Biology, v. 12, p. 259-266, 2009. http://dx.doi.org/10.1016/j.pbi.2009.05.006

KLIS, F. M. Review: Cell wall assembly in yeast. Yeast, v. 10, p. 851-869, 1994. http://dx.doi.org/10.1002/yea.320100702

LEE, J.; KALETUNÇ, G. Evaluation of the Heat Inactivation of Escherichia coli and Lactobacillus plantarum by Differential Scanning Calorimetry. Applied and Environmental Microbiology, v. 68, p. 5379-5386, 2002.

http://dx,doi.org/10.1128/AEM.68.11.5379-5386.2002

LEMOS, S. G.; TAKIYAMA, L. R. Avaliação de um método alternativo para a caracterização das propriedades ácido-base de substâncias húmicas aquáticas. Cadernos de Pesquisa, v.10, p. 22-35, 1999.

MADRID, Y.; CÁMARA, C. Biological Substrates for metals pre-concentration and speciation. Trends in Analytical Chemistry, v. 16, p.36-44, 1997. http://dx.doi.org/10.1016/S0165-9936(96)00075-1

MARCH, J. Advanced Organic Chemistry. New York: John Wiley \& Sons, 1992.

PEARSON, R. G. Hard and soft acids and bases HSAB, Part I Fundamental principles. $\begin{array}{lllllll}\text { Journal of Chemical Education, v. 45, p. 581-587, } 1968 . & \text {. }\end{array}$ http://dx.doi.org/10.1021/ed045p581

SHIEWER, S.; VOLESKY, B. Biosorption process for Heavy metal removal. In: LOVLEY, D. R. Environmental Microbe-Metal Interactions. Washington: ASM Pres, 2000.

VEGLIÒ, F.; BEOLCHINI, F. Removal of metals by biosorption: a review. Hydrometallurgy, v. 44, p. 301-316, 1997. http://dx.doi.org/10.1016/S0304386X(96)00059-X

VOLESKY, B. Sorption and biosorption, Québec: BV Sorbex, 2004.

WANG, J. M.; HUANG, C. P.; ALLEN, H. E.; TAKIYAMA, L. R.; POESPONEGORO, I.; POESPONEGORO, H.; PIRESTANI, D. Acid characteristics of dissolved organic matter in wastewater. Water Environmental Research, v. 70. p. 1041-1048, 1998. http://dx.doi.org/10.2175/106143098X123372 